\title{
РЕГЛАМЕНТАЦІЯ ПРАВА ПОСТІЙНОГО КОРИСТУВАННЯ ЗЕМЕЛЬНОЮ ДІЛЯНКОЮ: ДЕЯКІ ПРОБЛЕМИ ТА ПЕРСПЕКТИВИ КРІЗЬ ПРИЗМУ ОКРЕМИХ ПРАВОВИХ ПОЗИЦІЙ СУДОВОЇ ПРАКТИКИ
}

Тесля Л. В.

У науковій статті досліджено зміст окремого правового титулу - право постійного користування земельною ділянкою, його правову природу. Завдяки аналізу теоретичних положень, чинного законодавства та окремих позицій судової практики з'ясовано проблемні питання регламентації інституту права землекористування, його недоліки. Акцентовано увагу на перевагах трансформації права постійного користування земельноі ділянкою у право власності в сучасних умовах господарювання з відповідними змінами до законодавства. Виявлено неоднозначність судових позицій щодо переходу права постійного землекористування в порядку правонаступництва до громадян та юридичних осіб. Надано пропозиції законодавчо чітко визначити поняття «набуття права» й «перехід права», «припинення» юридичної особи $i$ «припинення діяльності» юридичної особи, що позитивно впливатиме на реалізацію прав суб'єктів, гарантованих законом.

Ключові слова: право постійного користування, земельна ділянка, право власності, правонаступник, фермерське господарство, спадкування/

В научной статье исследовано содержание отдельного правового титула - право постоянного пользования земельным участком, его правовую природу. На основании анализа теоретических положений, действующего законодательства и отдельных позиций судебной практики выяснено проблемные вопросы регламентации института права землепользования, его недостатки. Акцентировано внимание на преимуществах трансформации права постоянного пользования земельным участком в право собственности в современных условиях хозяйствования со внесением соответствующих изменений в законодательство. Выявлено неоднозначность судебных позиций по переходу права постоянного землепользования в порядке правопреемства $\kappa$ гражданам и юридическим лицам. Даны рекомендации законодательно четко определить понятие «приобретение права» $и$ «переход права», «прекращение» юридического лица и «прекращение деятельности» юридического лица, что положительно повлияет на реализацию прав субъектов, гарантированных законом.

Ключевые слова: право постоянного пользования, земельный участок, право собственности, правопреемник, фермерское хозяйство, наследование.

Teslia L. V. Regulation of the right to permanent use of land plot: some challenges and perspectives through the prism of individual judicial positions

The article is devoted to the study of the content of a separate legal title - right of permanent use of land plot, its legal nature. Based on the analysis of theoretical provisions, current legislation and individual positions of judicial practice, the problematic issues of regulation of the institute of land use law, its shortcomings have been clarified.
The disadvantage of the legal title of right of permanent use of land is the lack of the right of disposition, which negatively affects the economy of the state in the formation of a fullfledged land market, and creates a circumvention of the law.

The limited range of subjects of the right of permanent land use, which has significantly increased from 2004 to the present, is tied to the organizational and legal forms of management. It looks like a kind of "benefit" from the state and leads to a decrease revenues to the local budget in connection with a lower land tax rate compared to the rent for the use of state and communal lands. At the same time, it is necessary to improve the legal culture of both officials and citizens in order to prevent corruption in land relations.

The ambiguity of court positions on the transfer of the right of permanent land plot use in the order of succession to citizens and legal entities was revealed.

The land legislation of Ukraine does not contain either a direct rule or a clear prohibition on the transfer of right of permanent use of land in the order of succession to the subjects of such right. Instead, the court practice has a legal position in disputes arising on this issue and secures right of permanent use of land for successor, if any.

Article 92 of the Land Code of Ukraine is proposed to be supplemented by a separate part, according to which right of permanent use of land plot, which was granted for farming enterprise and is used for farming, can be inherited.

Proposals have been made to clearly define the concepts of "acquisition of law" and "transfer of law", "termination" of a legal entity and "termination of activity" of a legal entity, which will positively affect the implementation of the rights of entities guaranteed by law.

When considering disputes concerning inheritance of right of permanent use of land provided for farming enterprise, it is necessary to take into account the existing court practice, in particular the court practice of the European Court of Human Rights.

Key words: right of permanent use, land plot, property rights, successor, farming enterprise, inheritance.

Постановка проблеми та їі актуальність. Конституція України надає право громадянам та юридичним особам користуватись землею на визначених законом різних правових титулах. Чинне земельне законодавство передбачає можливість господарського панування на земельній ділянці як іï власника, так і користувача. Окремим правовим титулом, якому відповідають правомочності володіння й користування без установлення строку, $є$ право постійного користування, котре має свою історію. Нині склад суб'єктів, за якими можна закріпити право постійного землекорис- 
тування, відповідно до Земельного кодексу України від 25.10.2001 року, порівняно із Земельними кодексами УРСР від 08.07.1970 та від 18.12.1990 років, $є$ більш звуженим відповідно до інших правових титулів, а об'єктом цього права $є$ землі лише державної та комунальної власності. До того ж у законодавстві $\epsilon$ неузгодженості та недоліки щодо визначення понять «набуття права» постійного користування земельною ділянкою й «перехід прав та обов'язків» на земельну ділянку, «припинення» юридичної особи i «припинення діяльності» юридичної особи призводить до певних труднощів у питанні правонаступництва права постійного землекористування як громадян, що отримали земельні ділянки ще за радянських часів, так і юридичних осіб публічного та приватного права. Це породжує суперечки як на рівні «якості законодавства», так і в судових інстанціях, підтвердженням чого $\epsilon$ багато судових рішень із земельних питань, зокрема з питань права постійного користування земельною ділянкою. Виходом із цієі ситуації має бути системний аналіз правового регулювання інституту права постійного землекористування щодо його перспектив розвитку та доцільності в сучасних умовах. Такий аналіз має носити міждисциплінарний підхід із залученням спеціалістів правового, економічного та управлінського спрямування.

Аналіз останніх досліджень і публікацій. Проблемам правового регулювання земельних відносин, зокрема інституту права землекористування, присвятила праці низка науковців-правників: А.М. Мірошниченко, П.Ф. Кулинич, О.О. Погрібний, М.В. Шульга, І.І. Каракаш, В.П. Мироненко та інші. Водночас за всієї науково-практичної значимості праць окремі питання права постійного землекористування залишаються недостатньо дослідженими, що призводить до непорозумінь та зловживань розпорядчих органів у сфері земельних відносин, а також суб'єктів такого права, й потребує уваги.

Метою статті $\epsilon$ дослідження особливостей регламентації права постійного користування земельною ділянкою, а також проблемних питань щодо реалізації норм закону в разі правонаступництва вказаного правового титулу на основі теоретичних положень, відповідних чинних нормативно-правових актів, а також окремих правових висновків судової практики, й надання пропозицій щодо доцільності перспектив розвитку права постійного користування земельною ділянкою.

Виклад основного матеріалу. Інтерес науковців до правового регулювання земельних відносин $\epsilon$ закономірним, адже Україна володіє одним із найпотужніших земельних фондів у Європі. Із загальної площі 60 млн га 42,7 млн га $(70,8 \%)$ займають сільськогосподарські угіддя з дуже родючими ґрунтами. Ще 17,6\% території - ліси, 4,2\% - це забудовані території [10]. Потужний земельний фонд держави здатний задовольняти різноманітні потреби суспільства і $€$ ключовим для вдосконалення рівня життя населення за умови його ефективного раціонального використання. На це має бути спрямована політика держави.

Інститут права землекористування був іще за радянських часів. До започаткування земельної реформи в 1991 році він був доволі актуальним, оскільки приватної власності на землю тоді закріплено ще не було, всі землі мали державну форму власності і право постійного землекористування було своєрідним виходом для громадян та суб'єктів господарювання. Суб'єктами цього права було визнано як юридичних осіб, так і громадян. Із часом, у зв'язку із земельною реформою, прийняттям нових Земельних кодексів України і внесенням змін у чинне земельне законодавство інститут землекористування суттєво змінився. Право землекористування від постійного й тимчасового перетворилось на декілька форм і має класифікацію правових титулів. Чинне земельне законодавство вже не закріплює право постійного землекористування за громадянами та приватними юридичними особами з 01 січня 2002 року, що тягне неоднозначне тлумачення подальшої його правової долі.

Право землекористування розглядається дослідниками в різних аспектах, в об'єктивному та суб'єктивному розумінні. 3 одного боку - як інститут земельного права, сукупність правових норм, що регулюють здійснення суб'єктивного права землекористування, його виникнення, зміну та припинення. 3 іншого - як правомочність користування земельними ділянками, або як правовий титул, котрий надає фізичним та юридичним особам суб'єктивне право використовувати земельну ділянку, відмінний від права власності [1, с. 220].

Аналіз наукової літератури надає підстави стверджувати, що право постійного землекористування $\epsilon$ за своєю юридичною природою речовим правом на нерухоме майно, похідним від права власності, обмеженим у змісті з можливістю титульного володільця впливати на річ без участі власника, відповідно до закону чи договору.

Постійний виключний характер дослідженого правового титулу надає йому спільних рис із правом власності. Зокрема, спільними рисами $є$ : безстроковий, постійний характер; правомочність володіння та користування земельними ділянками; оплатний характер, зобов'язання сплачувати земельний податок; наявність майже однакових прав, відповідно до норм ЗКУ, й у сфері охорони земель; момент виникнення цих прав пов'язується з державною реєстрацією, за незначними виключеннями.

Щодо відмінностей, історично й фактично коло суб'єктів права власності та права користування земельною ділянкою не відрізняється, хоча юридично нині права постійного землекористування має обмежене коло суб'єктів; зміст суб'єктивних прав відрізняється правомочністю розпорядження, без права відчуження за умови постійного землекористування; підставами виникнення права власності $\epsilon$ цивільно-правові угоди щодо земельної ділянки та інші підстави, передбачені законодавством, а право постійного користування виникає тільки на підставі розпорядчого акта державного органу або органу місцевого самоврядування [2, с. 65]. Об'єктами права постійного землекористування $\epsilon$ земельні ділянки, які надаються з усіх категорій земель державної або комунальної власності [4, с. 101].

Доречно зауважити, що правомочність володіння й користування земельною ділянкою містить юридично забезпечену можливість впливу на річ та отримання корисних властивостей від речі для задоволення власних потреб. Правомочність розпорядження земельною ділянкою залишається за державою. Цей факт робить об'єкт права не таким привабливим і, як результат, «приховане» відчуження земельних ділянок за відчуження нерухомого майна або різноманітних «хитрих» 


\section{Проблеми \\ екологічного законодавства}

договорів на зразок договорів про спільну діяльність, інвестиційні договори тощо [1, с. 225].

Речове право, на відміну від зобов'язального, характеризується тим, що має абсолютний характер, із чого випливає закріплення вичерпного переліку прав у законі й реєстрація цього права; своїм предметом має індивідуально визначену річ; характеризується «правом слідування»; похідне, залежне від права власності як основного речового права [3, с. 308, 318].

Необхідно відрізняти окремий речовий титул на використання земельної ділянки від використання земельної ділянки з дозволу володільця титулу на зобов'язальному праві. Щодо державних земель, здебільшого вважається, що для будь-якого користування ними необхідний окремий речовий титул на земельну ділянку, зокрема, отримання земельної ділянки у власність, оренду тощо. Бувають ситуації, коли безпідставно органи державного контролю можуть вимагати речовий титул на земельну ділянку, хоча законодавчо закріплено її використання з дозволу власника [1, с. 221]. I в цьому також спостерігається одна із проблем джерела корупції в земельній сфері.

На думку професора А.М. Мірошниченка, право постійного користування в сучасних умовах має негативний вплив на економіку держави і $\epsilon$ шкідливим. Оскільки суб'єкт права постійного землекористування стикається із проблемами неможливості розпоряджатись земельною ділянкою навіть за згодою розпорядчого органу (власника), це призводить до обходу закону, приховування іншого права землекористування, породження корупційних «ніш» та підриву економіки. Виходом із цієї ситуації $\epsilon$ відмова від цього правового титулу і його трансформація в інший правовий титул, наприклад, право власності [1, с. 226].

На думку окремих дослідників, право постійного користування з обмеженим суб'єктним складом суперечить обов'язкам України щодо адаптації національного законодавства щодо законодавства ЄC. Зокрема, під кутом зору законодавства $Є С$ про конкуренцію (ст. 86.1 Угоди про заснування $Є C$ ), надання права постійного користування може розглядатись як державна допомога. Така допомога допускається, але в обмежених випадках і для певної виправданої мети [5, с. 69]. Як бачимо, у ЗКУ закріплена прив'язка не до мети, а до організаційно-правових форм господарювання. Водночас, якщо порівняти ч. 2 ст. 92 в редакції 2004 року та внесення змін та доповнень до цієї статті протягом 2004-2020 років, то коло суб'єктів із часом достатньо збільшилось. Такими суб'єктами, згідно із ч. 2 ст. 92 ЗКУ, крім підприємств, установ та організацій, котрі належать до державної та комунальної власності, а також громадських організацій осіб з інвалідністю України, їх підприємств (об'єднань), установ та організацій, стали релігійні організації України; публічне акціонерне товариство залізничного транспорту загального користування, утворене відповідно до Закону України «Про особливості утворення публічного акціонерного товариства залізничного транспорту загального користування»; заклади освіти незалежно від форми власності; співвласники багатоквартирного будинку для обслуговування такого будинку та забезпечення задоволення житлових, соціальних і побутових потреб власників (співвласників) та наймачів (орендарів) квартир та нежитлових приміщень, розташованих у багатоквартирному будинку; оператор газотранспортної системи та оператор системи передачі. $€$ спеціальні обмеження щодо користувачів земельних ділянок водного фонду та земель лісогосподарського призначення. Відповідно до ст.ст. 57, 59 ЗКУ такими суб'єктами можуть бути тільки державні водогосподарські організації та державні або комунальні лісогосподарські підприємства.

Земельний податок, який сплачують зазначені суб'єкти, відповідно до податкового законодавства, $\epsilon$ набагато меншим від орендної плати в разі користування земельною ділянкою на умовах оренди, котра виглядає як своєрідна «пільга» держави визначеним законодавством суб'єктам і $€$ також корупційним складником. Уникнення додаткових витрат, як під час оформлення, так і в майбутньому, - одна із причин розширення суб'єктного складу осіб, котрімають право на постійне землекористування.

Ураховуючи, що 3,2 млн га сільськогосподарських угідь перебуває в постійному користуванні державних і комунальних підприємств, установ та організацій і 1,5 млн га - у постійному користуванні фізичних осіб та юридичних осіб, які набули цього права за законодавством, котре діяло раніше [11], то, відповідно, під час зміни правового титулу права постійного землекористування, наприклад, на право оренди, місцеві бюджети суттєво наповняться, що призведе до додаткової матеріальної бази для розвитку сфери земельних відносин і може буде спрямоване на поліпшення певних територій, їх екологічного складника тощо, навіть за наявності переліку пільгових осіб за ст.ст. 281, 282 Податкового кодексу України.

Із часом, зі створенням повноцінного ринку землі, інститут права постійного землекористування повільно втрачатиме свою актуальність, адже позбавлений права розпорядження. Юридичні особи публічного права можуть бути трансформовані в господарські товариства, а держава чи територіальна громада будуть володіти ними через власність на статутний капітал. Це мало б надати їм більшу самостійність та додаткові можливості у веденні господарської діяльності. Однак цей факт може дозволити керівникам зазначених підприємств зловживати службовими повноваженнями і створити підґрунтя для масового необґрунтованого відчуження закріплених за ними земельних ділянок [8]. Тому, відповідно, необхідно вдосконалювати правову культуру як посадових осіб, так і громадян; запровадити ефективний правовий механізм беззаперечного притягнення посадових осіб до адміністративної або кримінальної відповідальності за корупційні злочини та правопорушення, пов'язані з корупцією, з можливістю залучення до відповідальності колегіального органу; а суб'єктам запобігання корупції своєчасно реагувати на повідомлення громадян про корупційні діяння у сфері земельних відносин.

Право постійного користування земельною ділянкою історично характерне для більшості держав, які входили до складу Радянського Союзу. У таких країнах, як Білорусь, Узбекистан, Вірменія, Туркменістан, і сьогодні земельні ділянки виділяються в постійне користування доволі широкому колу суб'єктів. Натомість у Росії та Казахстані правом постійного користування земельними ділянками наділене обмежене коло суб'єктів, а для більшої частини інших осіб передбачена чітка 
процедура переоформлення цього права у власність або в користування. У Латвійській Республіці право постійного користування використовувалось на проміжному етапі земельної реформи з подальшим його переоформленням у право власності на землю [11]. В Естонії набула популярності оренда земельних ділянок. Оскільки Україна стоїть на порозі земельного ринку, то отриманий досвід проведення земельної реформи, наприклад, у країнах Балтії, може стати інструментом до розуміння загальних тенденцій і перспектив щодо доцільності права постійного користування землею й можливості його трансформації в інші титули права.

Щодо нормативного визначення поняття права постійного землекористування, то, відповідно до ч. 1 ст. 92 Земельного кодексу України (надалі - ЗКУ), це право володіння й користування земельною ділянкою, яка перебуває в державній або комунальній власності, без установлення строку [12].

Згідно із ч. 2 ст. 4 Закону України «Про державну реєстрацію речових прав на нерухоме майно та їх обтяжень» право постійного користування земельною ділянкою виникає з моменту його державної реєстрації. Водночас оформлення його до 01 січня 2013 року визнається дійсним за наявності певних підстав. Так, якщо реєстрація його була проведена відповідно до законодавства, що діяло на момент його виникнення, а також на момент виникнення такого права діяло законодавство, яке не передбачало його обов'язкової реєстрації [15]. Цей факт $\epsilon$ немаловажним у зв'язку з еволюцією права постійного користування земельною ділянкою і $з$ його правонаступництвом.

Питання правонаступництва в теорії права розглядається як перехід прав та обов'язків від одного суб'єкта права до іншого за законом або угодою, водночас можливий перехід як повністю всіх прав та обов'язків суб'єкта (універсальне правонаступництво), так й окремих (сингулярне правонаступництво) [6, с. 329]. Реорганізацію юридичної особи, а також спадкування відносять до універсального правонаступництва. Як було зазначено вище, правонаступник вступає у права користувача саме з моменту державної реєстрації. Водночас, відповідно до ч. 1 ст. 104 Цивільного кодексу України (надалі - ЦКУ), під час реорганізації юридичної особи майно, права та обов'язки переходять до правонаступників, водночас, згідно із ч. 1 ст. 109 ЦКУ, перехід прав у разі виділу юридичної особи здійснюється шляхом передачі частини майна, прав та обов'язків за розподільчим балансом із моменту його підписання [13]. У такій ситуації підприємство свою діяльність не припиняє, i, відповідно, моментом переходу прав $\epsilon$ підписання розподільчого балансу, а не момент державної реєстрації. 3 позицій податкового законодавства виділ $\epsilon$ однією з форм реорганізації платника податків.

Порядок правонаступництва щодо таких речових прав на земельну ділянку, як право власності, право оренди, емфітевзис, суперфіцій, можуть передаватись у порядку спадкування, про що чітко визначено у ч. 1. Ст. 81, ч. 1 ст. 82, ч. 5 ст. 93, ч. 2 ст. 1021 ЗКУ. Відповідно до ч. 4 ст. 32 Закону України «Про оренду землі» реорганізація юридичної особи - орендаря не $\epsilon$ підставою для зміни умов або припинення договору, якщо інше не передбачено договором оренди землі [16]. Право земельного сервітуту, згідно із ч. 2 ст. 101 ЗКУ, не може передаватись будь-яким способом особою, в інтересах якої цей сервітут установлено, іншим фізичним та юридичним особам і, відповідно, припиняється в разі смерті особи, на користь якої був установлений.

Щодо права постійного користування земельною ділянкою, то земельне законодавство не містить як прямої норми, так і чіткої заборони щодо переходу такого права в порядку правонаступництва. Тлумачення ст. 19 Конституції України як неприпустимість примушення робити те, що не передбачено законодавством, та діяти органам державної влади й місцевого самоврядування лише на підставі Конституції та законів України, набуває широкого сенсу й наводить на висновок про перехід права постійного користування земельною ділянкою від однієї юридичної особи до іншої в порядку правонаступництва.

Однак, як зазначалось вище, перелік юридичних осіб, які, згідно із ч. 2 ст. 92 ЗКУ, можуть набувати права на постійне користування земельною ділянкою, звужений. І якщо юридична особа-правонаступник до цього переліку не входить, то, як наслідок, не має права на отримання земельної ділянки в постійне землекористування. У цьому питанні норми Земельного й Цивільного кодексів не кореспондують і закріплюють відповідно поняття «набуття права» постійного користування земельною ділянкою й «перехід прав та обов'язків» на неї. Згідно із ч. 2 ст. 92 ЗКУ поняття «набуття права» постійного користування земельною ділянкою пов'язано з первинним отриманням земельної ділянки від органів державної влади чи місцевого самоврядування. Поняття «перехід прав та обов'язків», згідно із ч. 1 ст. 104 ЦКУ, пов'язане з раніше набутим правом постійного землекористування. До того ж, відповідно до рішення Конституційного Суду України від 22.09.2005 року № 5-рп/2005 у справі № 1-17/2005, п. 5.4 поняття «набувають права», за змістом ч. 2 ст. 92 та ч. 1 ст. 116 ЗКУ, розповсюджується виключно на випадки первинного отримання земельної ділянки із земель державної або комунальної власності підприємствами, установами та організаціями, котрі належать до державної або комунальної власності, а також громадянами та юридичними особами, які набувають право власності на користування земельними ділянками. Відповідно до пункту 5.3 зазначеного рішення Конституційного суду України, положення ст. 92 ЗКУ не обмежують і не скасовують права постійного землекористування земельними ділянками, набутого в законному порядку на 01 січня 2002 року [14]. Таким чином, Конституційний суд України своїм рішенням поставив крапку на користь правонаступника.

У зв'язку з вищезазначеним, необхідно законодавчо закріпити поняття «набуття права» постійного користування земельною ділянкою та «перехід прав та обов'язків» на земельну ділянку постійного користування, визначивши відмінності первинного отримання земельної ділянки та правової долі вже набутого права постійного користування земельною ділянкою.

Наступна неузгодженість норм законодавства стосується припинення права користування земельною ділянкою в разі припинення діяльності релігійних організацій, державних чи комунальних підприємств, установ та організацій. У частині 1 ст. 141 ЗКУ та ч. 1 ст. 406 ЦКУ закріплено норми щодо «припинення діяльності» юридичної особи i, відповідно, «припинення юридичної особи». Щодо цього питання $\epsilon$ пра- 


\section{Проблеми \\ екологічного законодавства}

вова позиція Верховного Суду України в Постанові від 21.02.2011 року в адміністративній справі № 21-3a11 за позовом Сімферопольського міжрайонного природоохоронного прокурора до Фороської селищної ради. Відповідно до неї, аналіз зазначених норм земельного законодавства дає підстави для висновку, що припинення права користування земельною ділянкою через припинення підприємства, установи, організації допускається лише в разі, коли припинення останніх виключає правонаступництво [17]. Тобто Верховний Суд також на боці правонаступника.

3 огляду на наведене необхідно внести відповідні зміни до чинного законодавства для чіткого визначення вказаних понять із метою недопущення неоднозначного їх тлумачення.

Низка позитивних судових рішень вищих судових інстанцій з аналогічною позицією на користь правонаступників також допомагає знизити напруження навколо цього питання. Так, Вищий господарський суд України у справі № 927/845/16 від 25.05.2017 року залишив без змін постанову апеляційного суду. Судове рішення мотивовано тим, що у процесі реорганізації шляхом перетворення до Рибгоспу шляхом правонаступництва перейшли всі майнові права попередника, зокрема і право постійного користування спірною земельною ділянкою на підставі державного акта на право постійного користування землею від 13.02.1997. Водночас право постійного користування земельною ділянкою, набуте Рибгоспом у встановленому порядку до 01.01.2001, не втрачається внаслідок його не переоформлення підприємством, яке за новим Земельним кодексом від 25.10.2001 не може набувати права постійного землекористування, а зберігається за ним до погодження прав та обов'язків щодо такої земельної ділянки з вимогами чинного законодавства як за правонаступником того землекористувача, котрому було видано Державний акт на право постійного землекористування [18].

Незважаючи на позитивні рішення в судовій практиці, розповсюджені випадки, коли розпорядники земельних ділянок в особі певних державних органів чи органів місцевого самоврядування можуть просто не визнати за правонаступником реорганізованої особи статусу постійного землекористувача. А за «самовільне» зайняття земельної ділянки законодавством передбачена цивільна, адміністративна або кримінальна відповідальність. Прокуратура наділена повноваженнями подати позов про вилучення з користування правонаступника нібито “самовільно» зайнятої земельної ділянки. До компетенції органу розпорядження земельними ділянками належить прийняття рішення про передачу земельної ділянки до земель запасу, зокрема, про передачу земельної ділянку у власність чи оренду третім особам, а також можливість ініціювання судового провадження щодо стягнення збитків у розмірі неодержаної орендної плати за фактичне користування землею без належно оформленої документації та правовстановлюючого документа на вказану земельну ділянку. Адже документи на право постійного користування землею оформлені на реорганізовану юридичну особу, а щодо правонаступника такий статус заперечується, тож наявні проблеми з документами [7, с. 43, 44].

Так, у Постанові Верховного Суду України від 14.09.2016 у справі 703/5377/14-ц сформульовано таку правову позицію. Користування земельною ділянкою без правовстановлюючих документів позбавляє орендодавця права одержати дохід у вигляді орендної плати за землю, який він міг би отримати, якби його право не було порушено. В разі неукладення договору оренди, суперфіцію або інших правочинів як правових підстав для користування земельною ділянкою з вини користувача такий позов підлягає задоволенню [19]. Тому спірні питання з державним реєстратором чи податковим органом у такому разі необхідно вирішувати в судовому порядку для підтвердження статусу постійного користувача-правонаступника.

Щодо переходу прав та обов'язків постійного землекористувача в порядку спадкування, то також виникає низка проблемних питань. Так, відповідно до ч. 1 ст. 178 цКУ, об'єкти цивільних прав можуть вільно переходити від однієї особи до іншої в порядку правонаступництва чи спадкування, якщо вони не $\epsilon$ невід' $\epsilon$ ними від фізичної чи юридичної особи. Відповідно до ст. 1218 цКУ до складу спадщини належать всі права й обов'язки, що належали спадкодавцеві на момент відкриття спадщини й не припинились унаслідок його смерті. 3 одного боку, згідно зі ст. 1219 ЦКУ, до переліку прав та обов'язків особи, які не входять до складу спадщини, право постійного користування земельною ділянкою не належитья [13]. 3 іншого - спадкування прав на земельну ділянку, закріплене в ч. 1 ст. 1225 цкУ, вказує, що до спадкоємців переходить тільки право власності на земельну ділянку, а не право користування земельною ділянкою, зі збереженням їі цільового призначення. До переліку підстав припинення права користування земельною ділянкою смерть фізичної особи постійного землекористувача не належить, відповідно до ст. 141 ЗКУ. Перехід права користування на земельну ділянку можливий, відповідно до ч. 2, ч. 3 ст. 1225 ЦКУ, за умов переходу прав на житловий будинок, інші будівлі та споруди, на яких вони розміщені. В такому разі, враховуючи неоднозначність норм законодавства щодо спадкування зазначеного права, виходом може бути звернення із заявою щодо надання у власність або в оренду земельної ділянки, яка використовувалась для ведення фермерського господарства спадкодавцем-постійним землекористувачем, до відповідного розпорядчого органу.

$€$ низка судових спорів щодо спадкування права постійного користування земельними ділянками, наданими для ведення фермерського господарства. Адже отримання засновником фермерського господарства речового права на землю, зокрема набуття земельної ділянки в постійне користування, було умовою його діяльності. Чинний Земельний кодекс України та Закон України «Про фермерське господарство» [20] не містить норми, яка б дозволила фермерським господарствам мати у своєму складі земельні ділянки на праві постійного користування.

Водночас привертає увагу також специфічний речовий титул на земельну ділянку - «право довічного успадковуваного володіння земельними ділянками», який передбачався законодавством у 1990-1992 рр. i $\epsilon$ іншою правовою конструкцією, порівняно з постійним користуванням, хоча застосовувався за аналогією з нею. Необхідно зазначити, що втрата чинності законодавства щодо права довічного успадковуваного володіння землею не призвела ні до втрати, ні до звуження 
обсягу цього права, оскільки його зміст та обсяг має визначатись законодавством, яке діяло на момент його виникнення. На сьогодні такого правового титулу не закріплено, але і припинення його законодавчо в разі смерті особи не зафіксовано. Тому питання спадкування в цьому разі належить до кола прав, які можуть бути успадковані [26].

Аналіз судової практики з питання спадкування права постійного користування земельною ділянкою фермерами свідчить як про негативні, так і позитивні рішення Верховного Суду України. Правова позиція про те, що право постійного користування земельною ділянкою не може успадковуватись після смерті голови фермерського господарства та не належить до спадщини, певний час була домінуючою. Так, правові позиції ВСУ, викладені в Постанові від 05.10.2016 у справі № 181/698/14-ц, в Ухвалі від 23.11.2016 у справі № 657/731/14-ц, в Постанові від 31.10.2018 у справі № 178/447/16-ц вказують, що право користування земельною ділянкою, яке виникло в особи на підставі державного акта на право користування земельною ділянкою, не належить до спадщини й не передається спадкоємцям у порядку спадкування за законом і припиняється зі смертю особи, якій належало, без укладення відповідного договору про право користування земельною ділянкою із власником землі $[21,22,23]$.

Натомість Велика палата Верховного Суду у справі № 368/54/17 від 20.11.2019 відступила від наданого раніше правового висновку й зазначила позицію, що, враховуючи необхідність дотримання балансу індивідуального та публічного інтересу у вирішенні питання щодо спадкування «права довічного успадкованого володіння» земельною ділянкою, це право підлягає успадкуванню [24]. Також Постановою Верховного Касаційного цивільного Суду у справі № 188/1124/15-ц від 11.12.2019 право постійного користування земельною ділянкою може бути визнано таким, що успадковується [25]. Таким чином, інтереси фермерських господарств і спадкоємців дотримано, але, на думку Д.О. Навроцького, суд не врахував засади діяльності і створення фермерських господарств, окрім того, правові титули не $\epsilon$ схожими між собою та не враховано співвідношення земельної ділянки засновника з фермерським господарством [9].

На підставі вищезазначеного, доцільно ст. 92 Земельного кодексу України доповнити окремою частиною, відповідно до якої право постійного користування земельною ділянкою, яка була надана для ведення селянського (фермерського) господарства й використовується для ведення фермерського господарства, може передаватись у порядку спадкування.

У практиці Європейського суду з прав людини у справах «Рисовський проти України», «Кривенький проти України» проаналізовано питання власності в контексті ст. 1 протоколу № 1 Конвенції. Із цих справ можна зробити висновок, що право постійного користування землею $є$ власністю особи. Також держава (державні органи) не мають права «свавільно», всупереч вимогам закону, позбавляти особу права власності (чи права користування) [27; 28]. В разі, коли національне законодавство припустило неоднозначне або множинне тлумачення прав та обов'язків осіб, національні органи зобов'язані застосувати найбільш сприятливий для осіб підхід. Тобто вирішення колізій у законодавстві завжди тлумачиться на користь особи [29]. У зв'язку з цим необхідно зробити висновок про те, що право постійного користування земельною ділянкою, яке особи набули до набрання чинності Земельного кодексу України в редакції 2001 року, в разі смерті особи підлягає успадкуванню. Зазначений висновок відповідає принципу Верховенства права [30].

Висновки. Спираючись на вищезазначене, констатуємо та пропонуємо:

по-перше, право постійного користування земельною ділянкою $\epsilon$ речовим правом на нерухоме майно, похідним від права власності, яке має як спільні риси, так і відмінності із правом власності. Недоліком правового титулу права постійного користування $\epsilon$ відсутність правомочності розпорядження, що негативно впливає на економіку держави під час становлення повноцінного ринку землі, та породжує обхід закону;

по-друге, обмежене коло суб'єктів права постійного користування земельною ділянкою, яке суттєво збільшилось із 2004 року донині, прив'язано саме до організаційно-правових форм господарювання, що виглядає як своєрідна «пільга» від держави та призводить до зменшення надходжень до місцевого бюджету у зв'язку з меншою ставкою земельного податку порівняно з орендною платою за використання земель державної та комунальної власності;

по-третє, за зміни правового титулу права постійного землекористування, наприклад, на право оренди земельної ділянки, місцеві бюджети суттєво наповняться, що призведе до додаткової матеріальної бази й може буде спрямовано на поліпшення певних територій, їх екологічний складник тощо. Мінусом є строковий характер орендних відносин. Водночас необхідно вдосконалювати правову культуру як посадових осіб, так і громадян із метою недопущення корупційного складника в земельних відносинах;

по-четверте, невизначеність суті термінів негативно впливає на практику здійснення суб'єктивних прав на земельні ділянки громадянами та юридичними особами. Від чіткого визначення сутності понять «набуття права» й «перехід права», «припинення юридичної особи» $\mathrm{i}$ «припинення діяльності» юридичної особи в законодавстві залежить можливість здійснення громадянами та юридичними особами гарантованого Конституцією України як права власності на землю, так і права користування нею, тому необхідно законодавчо чітко визначитись із поняттями та їх тлумаченням;

по-п'яте, земельне законодавство України не містить як прямої норми, так і чіткої заборони щодо переходу права постійного користування земельної ділянкою в порядку правонаступництва до юридичних осіб. Натомість судова практика має правову позицію у спорах, котрі виникають щодо цього питання й закріплює право постійного користування земельною ділянкою за правонаступником у разі наявності такого;

по-шосте, ст. 92 Земельного кодексу України пропонується доповнити окремою частиною, відповідно до якої право постійного користування земельною ділянкою, яка була надана для ведення селянського (фермерського) господарства й використовується для ведення фермерського господарства, може бути успадковане;

по-сьоме, під час розгляду спорів щодо спадкування права постійного користування земельною 
ділянкою, наданою для ведення фермерського господарства, варто брати до уваги наявну судову практику, зокрема судову практику Європейського Суду з прав людини.

\section{Література}

1. Мірошниченко А.М. Земельне право України : підручник. 2-е видання, допов. і перероб. Київ, Алерта; ЦУЛ, 2011.678 c.

2. Федик Є.І., Федик С.Є., Гентош Р.Є., Луцький І.М., Котуха О.С. Земельне право України : навчальний посібник. Львів : «Новий світ-2000», 2015. 218 с.

3. Маттеи У., Суханов Е.А. Основные положения права собственности. Москва : Изд-во «Юристъ», 1999. 384 с.

4. Земельне право України : підручник / за ред. 0.0. Погрібного, І.І. Каракаша. Київ, Істина, 2003, 448с.

5. Шляхи підвищення ефективності управління земельними ресурсами міст України. Київ : ІРЦ «Реформування земельних відносин в Україні», 2005. 335 с.

6. Юридична енциклопедія: у 6 т. / за ред. Ю.С. Шемшученка та ін. Київ : «Українська енциклопедія» ім. М.П. Бажана, 2003. Т. 5. 784 с.

7. Висоцька І.О. Право постійного користування землею: чи можливе правонаступництво? Землевпорядний вісник. № 10. 2019. с. 41-45.

8. Кулініч О.П. Право постійного користування землею: чотири способи вирішення проблеми. URL: https:// protocol.ua/ua/pravo_postiynogo_koristuvannya_zemleyu_ chotiri_sposobi_virishennya_proprobl/ (дата звернення 08.06.2020).

9. Навроцький Д.О. Аналіз окремих судових позицій щодо захисту прав на землю фермерського господарства. URL: https: / /www.hsa.org.ua/blog/analiz-okremyh-sudovyhpozytsij-shhodo-zahystu-prav-na-zemlyu-fermerskogogospodarstva/ (дата звернення 08.06.2020).

10. Нізалов Д.В. Стратегія земельної реформи України до 2024 року. URL: https://voxukraine.org/uk/strategiyazemelnoyi-reformi-v-ukrayini-do-2024-roku/ (дата звернення 07.06.2020).

11. Федун А.Д. Право постійного користування земля ми: між минулим та майбутнім. URL: https://agroportal.ua/ ua/views/blogs/pravo-postoyannogo-polzovaniya-zemlyamimezhdu-proshlym-i-budushchim/ (дата звернення 09.06.2020).

12. Земельний кодекс України від 25.10.2001 № 2768-III. URL: https://zakon.rada.gov.ua/laws/show/2768-14 (дата звернення 07. 06. 2020).

13. Цивільний кодекс України від 16.01.2003 № 435VI. URL: https://zakon.rada.gov.ua/laws/show/435-15 (дата звернення 07. 06. 2020).

14. Справа про постійне користування земельними ділянками: Рішення Конституційного Суду України № 5-рп/2005 від 22.09.2005. URL: http: / /zakon4.rada.gov.ua/ laws/show/v005p710-05 (дата звернення 07. 06. 2020).

15. Про державну реєстрацію речових прав на нерухоме майно та їх обтяжень : Закон України від 01.07.2004 № 1952 - IV. URL: https: //zakon.rada.gov.ua/ laws/show/742-15 ( дата звернення 09.06.2020).

16. Про оренду землі : Закон України від 06.10.1998 № 161-XIV. URL: https://zakon.rada.gov.ua/laws/show/ 161-14 (дата звернення 09.06.2020).
17. Постанова Верховного Суду України № 21-3a11 від 21.02.2011. URL: http://reyestr.court.gov.ua/Review/ 14405500 (дата звернення 09.06.2020).

18. Постанова Вищого господарського суду України № 927/845/16 від 25.05.2017. URL: http://reyestr.court.gov.ua/ Review/66799770 (дата звернення 09.06.2020).

19. Постанова Судової палати у цивільних та господарських справах Верховного Суду України № 703/5377/14-ц від 14.09.2016. URL: http://reyestr.court.gov.ua/Review/ 62058420 (дата звернення 09.06.2020).

20. Про фермерське господарство : Закон України від 19.06.2003 № 973-IV. URL: https://zakon.rada.gov.ua/laws/ show/973-15 (дата звернення: 10.06.2020).

21. Постанова Судової палати в цивільних справах Bepховного Суду України № 181/698/14-ц від 05.10.2016. URL: http://www.reyestr.court.gov.ua/Review/61942656 (дата звернення 10.06.2020).

22. Ухвала Судової палати у цивільних справах Верховного Суду України № 657/731/14-ц від 23.11.2016. URL: http://www.reyestr.court.gov.ua/Review/63213030 (дата звернення 10.06.2020).

23. Постанова Касаційногоцивільного судуускладіВерховного Суду України № 178/447/16-ц від 31.10.2018. URL: http://www.reyestr.court.gov.ua/Review/77653823 (дата звернення 09.06.2020).

24. Постанова Великої Палати Верховного Суду України № 368/54/17 від 20.11.2019. URL: http:// www. reyestr.court.gov.ua/Review/86105173 (дата звернення 11.06.2020).

25. Постанова Касаційного цивільного Суду у складі Верховного Суду України № 188/1124/15-ц від 11.12.2019. URL: http://www.reyestr.court.gov.ua/Review/ 86607167 (дата звернення 09.06.2020).

26. Мірошниченко А.М. Науковий висновок щодо застосування норм права, які регулюють відносини щодо права довічного успадковуваного володіння земельною ділянкою. URL: https://eucon.ua > wp-content > uploads > 2020/01 (дата звернення 11.06.2020).

27. Рішення ЄСПЛ у справі «Рисовський проти України» (Заява № 29979/04) від 20.10.2011. URL: https:// zakon.rada.gov.ua/laws/show/974_854\#Text (дата звернення: 10.06 .2020$)$.

28. Рішення ЄСПЛ у справі «Кривенький проти України» (Заява № 43768/07) від 16.02.2017. URL: https:// zakon.rada.gov.ua/laws/show/974_d48\#Text ( дата звернення: 10.06.2020).

29. Рішення ЄСПЛ у справі «Щокін проти України» ( Заява № 23759/03 та 37943/06 ) від 14.10.2010. URL: https://zakon.rada.gov.ua/laws/show/974_858 (дата звернення: 11.06.2020).

30. Рішення Апеляційного суду Полтавської області України № 525/1385/16-ц від 03.08.2017. URL: http:// www.reyestr.court.gov.ua/Review/68118317 (дата звернення: 11.06 .2020$)$.

Тесля Л. В., кандидат юридичних наук, викладач кафедри економічної теорії і економіки підприємства одеського державного аграрного університету 